Article

\title{
Preparation of Cross-Linked Enzyme Aggregates (CLEAs) of an Inulosucrase Mutant for the Enzymatic Synthesis of Inulin-Type Fructooligosaccharides
}

\author{
Thanapon Charoenwongpaiboon ${ }^{1}{ }^{\mathbb{D}}$, Rath Pichyangkura ${ }^{1}$, Robert A. Field ${ }^{2}$ \\ and Manchumas Hengsakul Prousoontorn ${ }^{1, *}$ \\ 1 Department of Biochemistry, Faculty of Science, Chulalongkorn University, Phayathai Road, \\ Bangkok 10330, Thailand \\ 2 Department of Biological Chemistry, John Innes Centre, Norwich Research Park, Norwich NR4 7UH, UK \\ * Correspondence: manchumas.h@chula.ac.th; Tel.: 66-2-218-5437
}

Received: 9 July 2019; Accepted: 25 July 2019; Published: 27 July 2019

check for updates

\begin{abstract}
Fructooligosaccharides are well-known carbohydrate molecules that exhibit good probiotic activity and are widely used as sweeteners. Inulin-type fructooligosaccharides (IFOs) can be synthesized from sucrose using inulosucrase. In this study, cross-linked enzyme aggregates (CLEAs) of Lactobacillus reuteri 121 inulosucrase (R483A-LrInu) were prepared and used as a biocatalyst for IFOs production. Under optimum conditions, R483A-LrInu CLEAs retained $42 \%$ of original inulosucrase activity. Biochemical characterization demonstrated that the optimum $\mathrm{pH}$ of inulosucrase changed from 5 to 4 after immobilization, while the optimum temperature was unchanged. Furthermore, the $\mathrm{pH}$ stability and thermostability of the R483A-LrInu CLEAs was significantly improved. IFOs product characterization indicated that the product specificity of the enzyme was impacted by CLEA generation, producing a narrower range of IFOs than the soluble enzyme. In addition, the R483A-LrInu CLEAs showed operational stability in the batch synthesis of IFOs.
\end{abstract}

Keywords: inulosucrase; cross-linked enzyme aggregates; fructooilgosaccharide

\section{Introduction}

Inulin-type fructooligosaccharides (IFOs) are well known as excellent prebiotics since they promote the growth of beneficial bacteria in the colon [1]. Additionally, IFOs have also been used as a low-calorie sweetener [2]. They can be synthesized enzymatically from sucrose using a $\beta$-fructofuranosidase (E.C. 3.2.1.26) derived from fungal species such as Aspergillus niger [3,4], Aspergillus japonicas [5,6], Aspergillus kawachii [7], and Aspergillus oryzae [8]. In addition, IFOs have been synthesized by hydrolysis of inulin using endo-inulinase [9,10].

Inulosucrase (E.C. 2.4.1.9) is a fructosyltransferase found in many bacterial species such as Leuconostoc citreum [11], Lactobacillus reuteri [12], Lactobacillus johnsonii [13], Lactobacillus gasseri [14], and Streptomyces viridochromogenes [15]. In comparison with fungal $\beta$-fructofuranosidase, inulosucrase has a higher transglycosylation activity [16]; it synthesizes both inulin and IFOs from sucrose, while $\beta$-fructofuranosidase mainly produces hydrolysis products and short chain oligosaccharides. Production of inulin and IFOs using inulosucrase has been reported with both soluble and immobilized enzymes, the latter being frequently used to increase the stability and reusability of enzymes [17-19]. The efficiency of immobilized biocatalysts is dependent on the supporting material and the linker used. The enzyme can be immobilized on either inorganic or organic materials via bifunctional cross-linkers, or without the supporting carriers. A well-known carrier-free immobilization technique, which has attracted extensive attention, involves the generation of cross-linked enzyme aggregates (CLEAs). 
CLEAs are prepared by precipitating the target enzyme using precipitating agents (salts, organic solvents, and non-ionic polymers), followed by cross-linking using bifunctional cross-linkers [20,21]. This technique provides insoluble and highly concentrated enzymes with enhanced operational and storage stability, which can be freely separated from the reaction by filtration or centrifugation. Many studies have revealed that this method can be applied to a broad range of carbohydrate-modifying enzymes, for instance $\alpha$-amylase [22], $\beta$-galactosidase [23], and levansucrase [24]. Nevertheless, to the best of the authors' knowledge, only our work has reported on IFOs synthesis using an immobilized inulosucrase [25] and no reports have been made on the preparation of CLEAs of inulosucrase. To fully understand the potential application of the different forms of immobilized inulosucrase for IFOs synthesis, further studies are required.

Recently, we reported a series of mutations of L. reuteri 121 inulosucrase, with the mutant R483A (R483A-LrInu) showing potential application for the production of IFOs [26,27]. In the present study, R483A-LrInu was prepared as a CLEAs format, with the optimization of reaction conditions. The activity of the resulting CLEAs was improved by Triton- $X$ treatment. The biochemical properties of R483A-LrInu CLEAs were assessed and compared to those of the corresponding soluble enzyme. Finally, the resulting CLEAs of the inulosucrase mutant were used as a biocatalyst for IFOs production.

\section{Results and Discussion}

\subsection{Preparation of Immobilized Inulosucrase Mutant}

CLEAs are usually prepared by two steps, precipitation of the enzyme from an aqueous solution and cross-linking of this aggregated enzyme with a bifunctional cross-linking agent. In this study, six different protein precipitating agents were investigated, analyzed and compared. Activity assays showed that, of the tested precipitants, ammonium sulfate provided the highest recovered activity of R483A-LrInu $(79.0 \pm 6.1 \%)$ (Figure 1A). The optimum amount of ammonium sulfate required for activity recovery was then investigated, using a concentration range of $2-40 \%(w / v)$ ammonium sulfate. It can be seen that the precipitated enzyme can retain $85.5 \pm 9.4 \%$ of its initial enzyme activity using $40 \%$ $(w / v)$ of ammonium sulfate (Figure 1B). These results are consistent with earlier reports that ammonium sulfate has been used to prepare a high enzyme activity of various CLEAs, such as $\alpha$-amylase [22], $\beta$-galactosidase [23], lipase [28], tyrosinase [29,30], subtilisin [31], phytase [32], feruloyl esterase [33], invertase [34,35], and levansucrase [24].
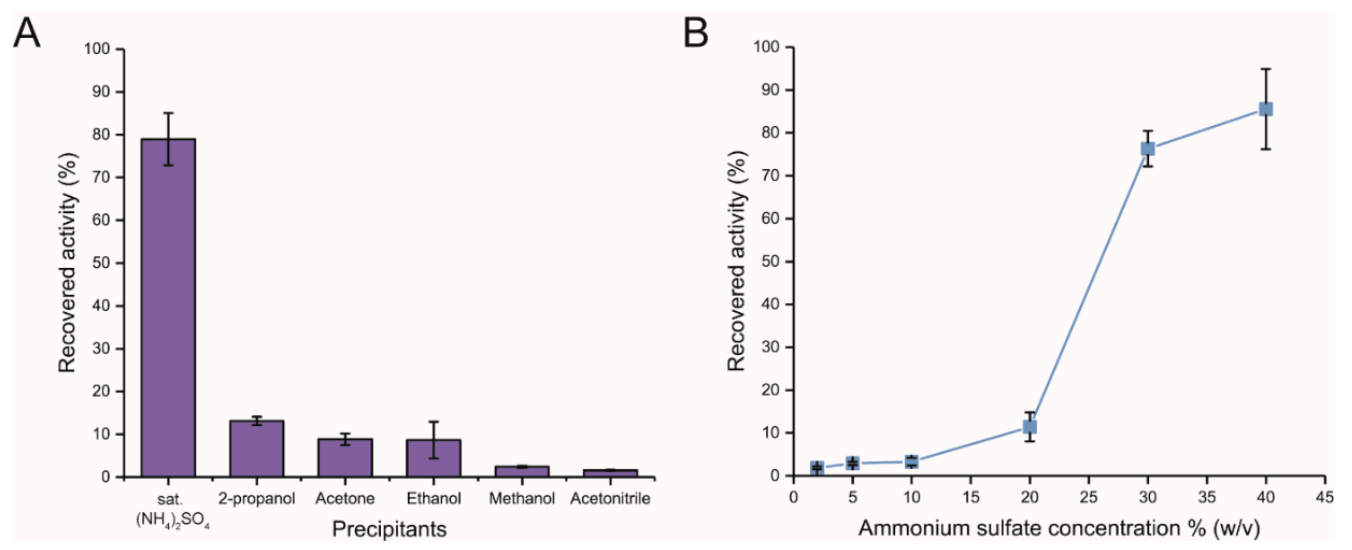

Figure 1. (A) Precipitation of R483A-LrInu with different precipitating agents. (B) The effect of ammonium sulfate concentration on the recovered activity of precipitated R483A-LrInu. The data represent the mean of three assays and the error bars represent the standard deviation of three experiments.

The effect of cross-linker concentration on CLEA activity was further explored using different final glutaraldehyde concentrations of $0-2 \%(v / v)$. It was found that the highest recovered activity was 
achieved when the enzyme was cross linked with $0.5 \mathrm{mM}$ glutaraldehyde (Figure $2 \mathrm{~A}$ ). The effect of cross-linking $\mathrm{pH}$ was also investigated in the $\mathrm{pH}$ range of 4-8. At $\mathrm{pH} 5-7$, the enzyme retained the highest activity (Figure 2B). The $\mathrm{pH}$ may affect the stability of the enzyme during the cross-linking process. Moreover, $\mathrm{pH}$ also affects the cross-linking mechanism of glutaraldehyde, influencing the rigidity or flexibility of CLEAs [21,36,37]. Subsequently, the effect of cross-linking time was explored and it was found that cross-linking at $4{ }^{\circ} \mathrm{C}$ for $3 \mathrm{~h}$ was optimal, and the recovered activity of CLEAs gradually decreased when the cross-linking time increased beyond that (Figure 2C). The R483A-LrInu CLEAs prepared under these conditions showed a retention of $35.4 \pm 4.1 \%$ of initial LrInu activity. The reduction in enzyme activity on CLEA formation may result from conformational changes of enzymes after the cross-linking process or the shielding of the catalyst active site by other aggregated proteins after precipitation. To reduce the effect of enzyme aggregation on LrInu activity, the CLEAs were incubated with $0.1 \%$ Triton-X100, a nonionic surfactant, for $1 \mathrm{~h}$. From the results in Figure 2D, it can be seen that the precipitated enzyme activity was improved $(42.0 \pm 6.0 \%)$, when compared to that of the untreated CLEAs. This suggested that Triton-X might remove non-specific hydrophobic interaction between the aggregated enzymes molecules, thereby increasing the rate of substrate/product diffusion to/from the active site. Under this condition, the CLEAs have an immobilization yield of about $94 \%$ with a specific activity of $53 \mathrm{U} / \mathrm{mg}$ (Table S1).

A

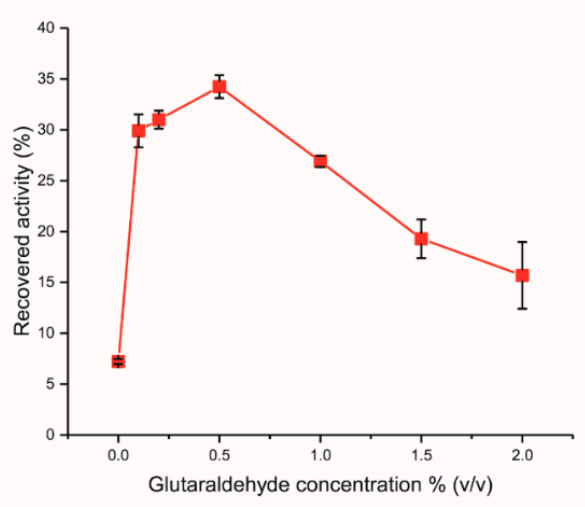

C

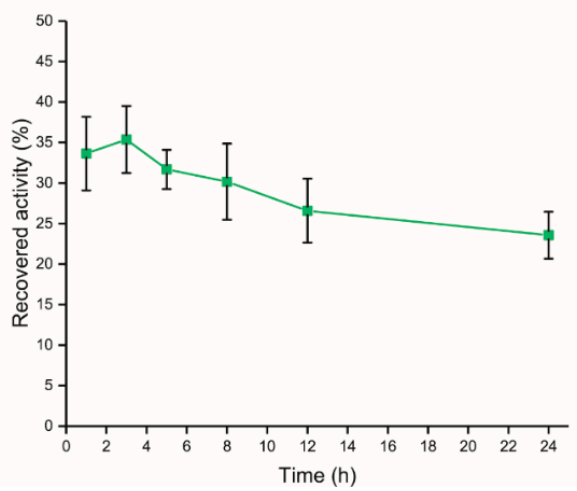

B

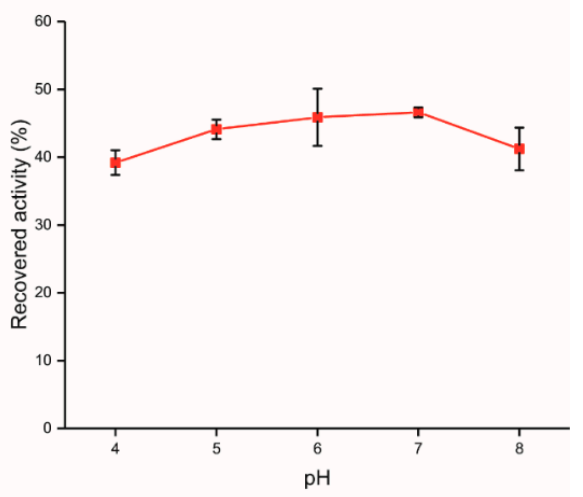

D

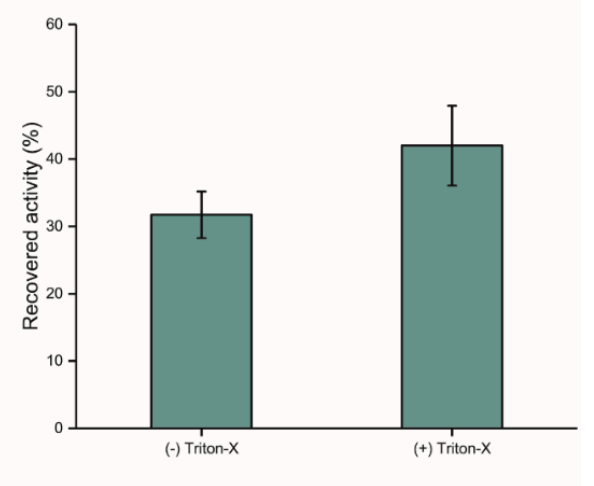

Figure 2. Effect of (A) glutaraldehyde concentration, (B) pH, (C) incubation time, and (D) Triton-X100 treatment on the recovered activity of CLEAs. The data represent means of three assays and the error bars represent the standard deviation.

\subsection{Biochemical Characterization of Free and Immobilized R483A-LrInu}

The optimum $\mathrm{pH}$ and temperature of the R483A-LrInu CLEAs were determined and compared to those of the free enzyme. The result demonstrated that the optimum $\mathrm{pH}$ of CLEAs was shifted to 4.0. The optimum $\mathrm{pH}$ of free inulosucrase was at $\mathrm{pH}$ 5.0, which was consistent with a previous report [38]. The $\mathrm{pH}$ profile showed that CLEAs exhibited $20-60 \%$ relative activity in the alkaline range ( $\mathrm{pH} 8.0-10.0)$, whereas the free enzyme completely lost its activity $(<5 \%$ relative activity) 
(Figure 3A). The shift of optimum $\mathrm{pH}$ might result from the change in ionization of amino acid residues in the microenvironment around the active site. This finding has been described for $\alpha$-amylase [22], tyrosinase [29], and lipase [39]. The optimum temperature for free and immobilized R483A-LrInu was found to be the same at $50{ }^{\circ} \mathrm{C}$. However, the temperature profile of the CLEAs format was broader than the free enzyme. CLEAs still exhibited $15-35 \%$ of inulosucrase relative activity at $60-70{ }^{\circ} \mathrm{C}$, while the free inulosucrase was inactive ( $<5 \%$ relative activity) (Figure $3 \mathrm{~B})$. This finding suggested that the immobilization of inulosucrase in a CLEA format was able to preserve activity and increase the stability of the enzyme, resulting in a catalyst that is active in a wider range of conditions.

A

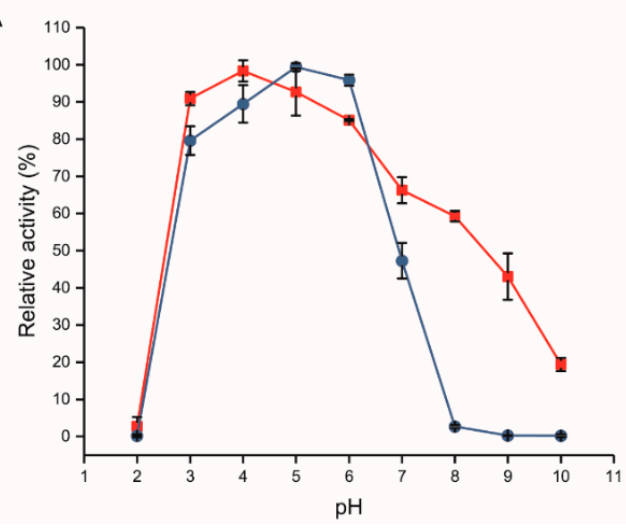

B

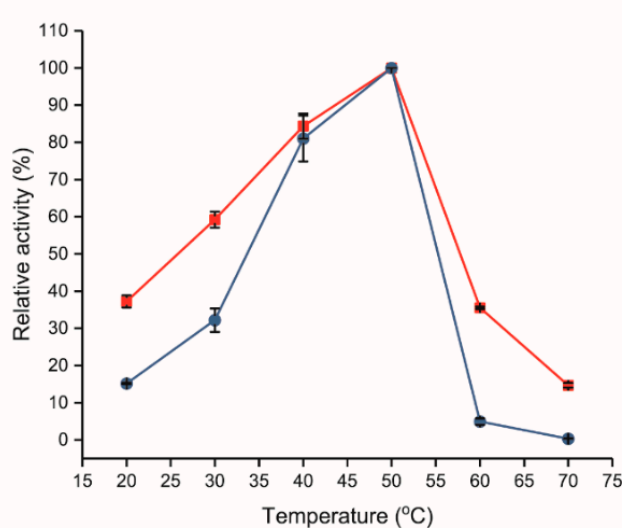

Figure 3. Effect of (A) pH and (B) temperature on the activity of free (blue line) and CLEAs R483A-LrInu (red line).

The $\mathrm{pH}$ stability of free and CLEA R483A-LrInu was investigated in the buffer $\mathrm{pH}$ range, 3.0-8.0, reflecting the high stability of the enzyme in this range ( $>50 \%$ relative activity). As shown in Figure $4 \mathrm{~A}$, both free and CLEAs of R483A-LrInu are stable in a broad pH range (3.0-8.0). Nonetheless, the CLEAs are more stable than the free inulosucrase, essentially retaining $100 \%$ of its initial activity in the $\mathrm{pH}$ range of $6.0-8.0$, while the free inulosucrase retained only $80 \%$ (Figure $4 \mathrm{~A}$ ). This result suggested that the preparation of inulosucrase as a CLEA has the potential to prevent the degradation or denaturation of inulosucrase during a $\mathrm{pH}$ change in the solution. For thermostability, both free and CLEA forms of R483A-LrInu were incubated at $50{ }^{\circ} \mathrm{C}$ for $9 \mathrm{~h}$. Under these conditions, the CLEAs retained activity as high as $70 \%$ of its initial activity, whereas the free R483A-LrInu retained only $50 \%$ at the same temperature (Figure 4B). The cross-linking approach could prevent the denaturation of enzyme molecules and stabilize the active conformation of the enzyme at high temperatures.

A

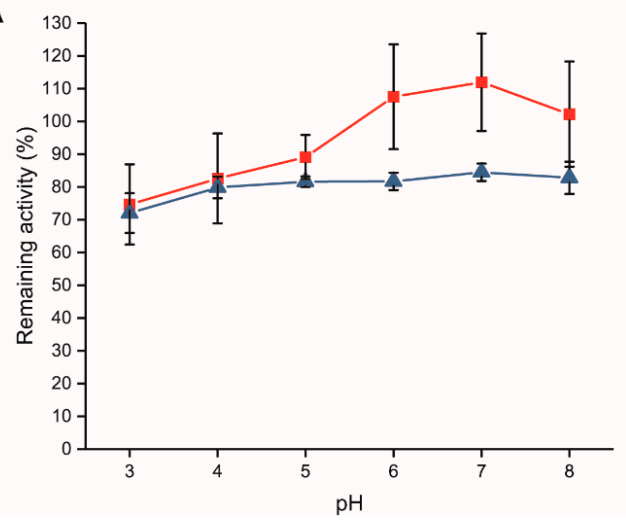

B

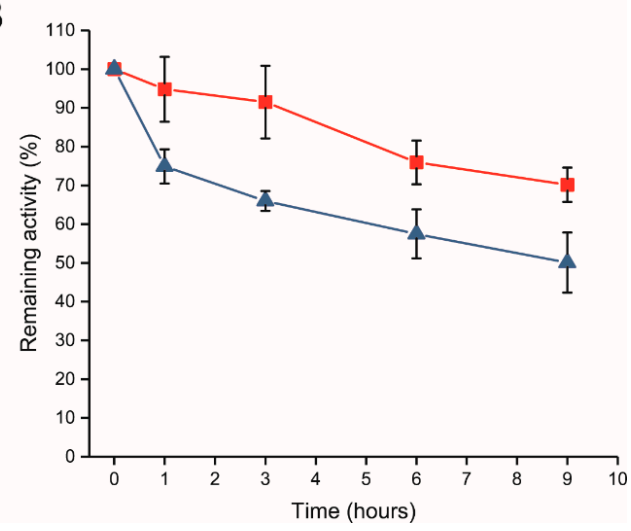

Figure 4. Effect of (A) $\mathrm{pH}$ and (B) temperature on the stability of free (blue line) and CLEAs R483A-LrInu (red line). 


\subsection{IFOs Synthesis Using Free and Immobilized R483A-LrInu}

Enzyme immobilization is a technique that provides a microenvironment which prevents, or at least reduces, enzyme inactivation. Multiple covalent linkages might result in conformational changes of protein and may affect the product specificity. To explore the influence of immobilization on the IFOs product profile, thin layer chromatography (TLC) analysis of IFOs derived from free and immobilized R483A-LrInu was employed. The result demonstrated that the patterns of IFOs synthesized from free and immobilized R483A-LrInu were significantly different (Figure 5A). Matrix assisted laser desorption and ionization time-of-flight mass spectrometry (MALDI-TOF MS) analysis showed that the CLEAs synthesized shorter chains of IFOs, with the degree of polymerization (DP) ranging from 3-8, while the soluble R483A-LrInu synthesized somewhat longer IFOs, with the DP up to 13 (Figure S1). The change of the IFOs pattern produced by R483A-LrInu CLEAs suggested that they may provide a microenvironment for enzyme molecules, which allowed only specific acceptors to diffuse into the enzyme active site, increasing product specificity. This finding was reported for other immobilized fructosyltransferases, such as levansucrase immobilized on vinyl sulfone-activated silica, which selectively produced levan-type fructooligosaccharides (LFOSs), while soluble levansucrase produced both LFOSs and levan [40].
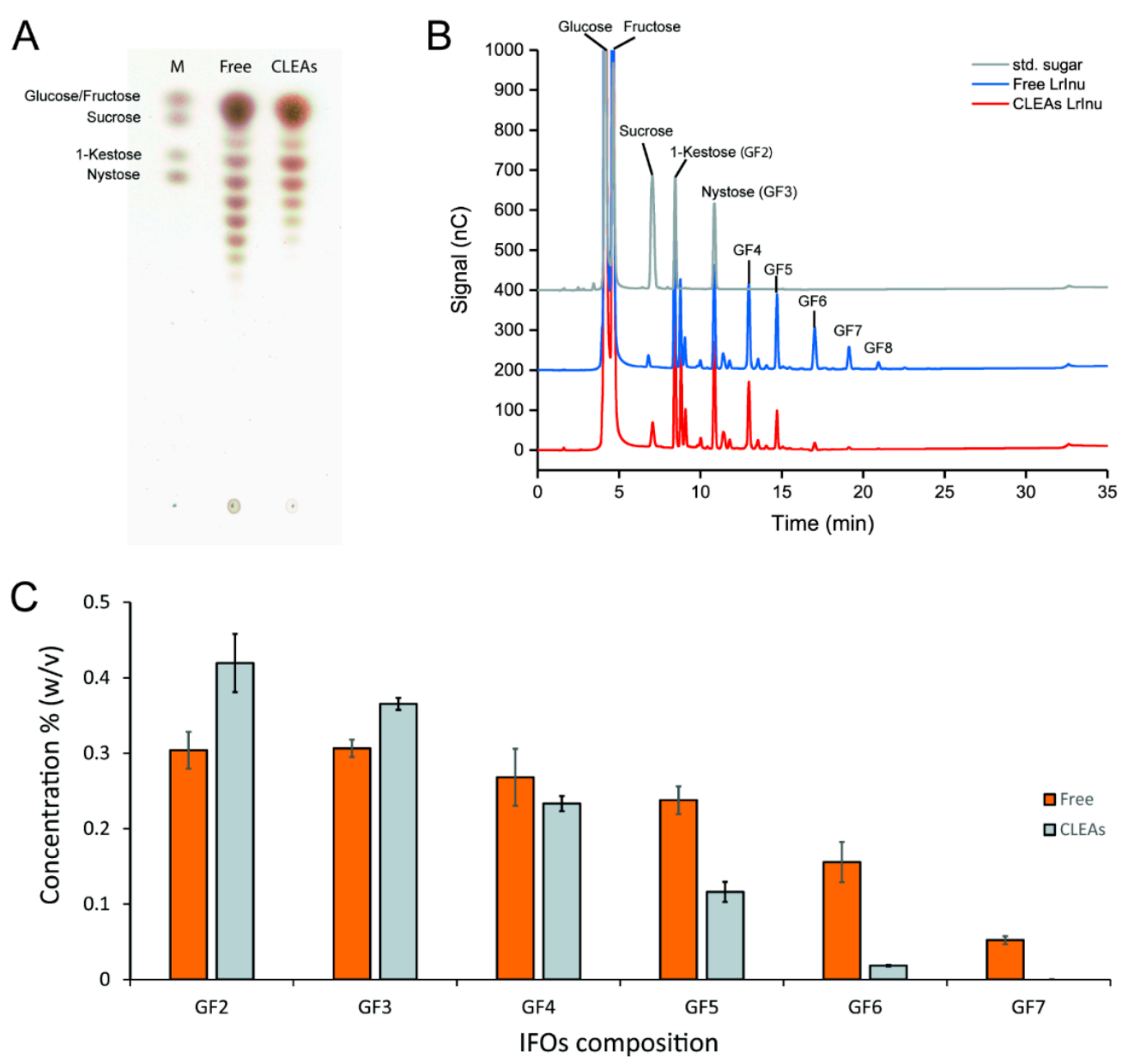

Figure 5. (A) TLC analysis of IFOs profiles synthesized by free and immobilized inulosucrase; lane $M$ indicated the standard sugar. (B) HPAEC chromatogram of standard sugars and IFOs synthesized by free and immobilized inulosucrase. (C) IFOs compositions analyzed by HPLC with an Asahipak NH2P-50 4E column.

High performance liquid chromatography with pulsed amperometric detector (HPAEC-PAD) was also performed to confirm the findings of TLC analysis. The HPAEC result indicated that 
immobilization did not affect the linkage type of IFOs produced by R483A-LrInu, because all peaks observed on HPAEC profiles of both free and immobilized enzymes were located at the same position (Figure 5B). Quantitative analysis of IFOs produced by free and immobilized enzymes were also performed by High performance liquid chromatography (HPLC) with amino column (Figure 5C) (Asahipak NH2P-50 4E $\mathrm{E}^{\mathrm{TM}}$ column, Shodex, Tokyo, Japan). The result showed that R483A-LrInu CLEAs produced a higher amount of GF3 and GF4 (abbreviation GFn was defined as the IFOs containing 1 unit of glucose and $n$ unit of fructose) and a lower amount of GF5-GF7, compared with the free enzyme. This finding indicated that preparation of inulosucrase as CLEAs can regulate the size of IFOs synthesized. Many studies showed that the biological activity of inulin is strongly dependent on its degree of polymerization. For example, IFOs with DP 2-8 show higher prebiotic activity than DP $>9$ [41]. IFOs with DP 4 increased immunoglobulin A (IgA) secretion and enhanced IFN- $\gamma$ and IL-10 production in the cecal CD4 ${ }^{+} \mathrm{T}$ cells in a rat [42]. Moreover, IFOs with DP $4-7$ also had modest anti-oxidant activity [43]. Therefore, the R483A-LrInu CLEAs might be useful for the synthesis of bioactive oligosaccharides.

Furthermore, the total IFOs produced by R483A-LrInu CLEAs were quantified using HPLC with a Sugar-Pak ${ }^{\mathrm{TM}}$ column (Waters Corp., Milford, MA, USA) (Figure 6). The result showed that R483A-LrInu CLEAs could synthesize the total IFOs up to $1.2 \%(w / v)$ after incubating with $5 \%(w / v)$ sucrose for $4 \mathrm{~h}$. After that, the amount of IFOs slightly decreased and seemed to be constant at approximately of $1 \%(w / v)$, although the reaction was performed for $30 \mathrm{~h}$.

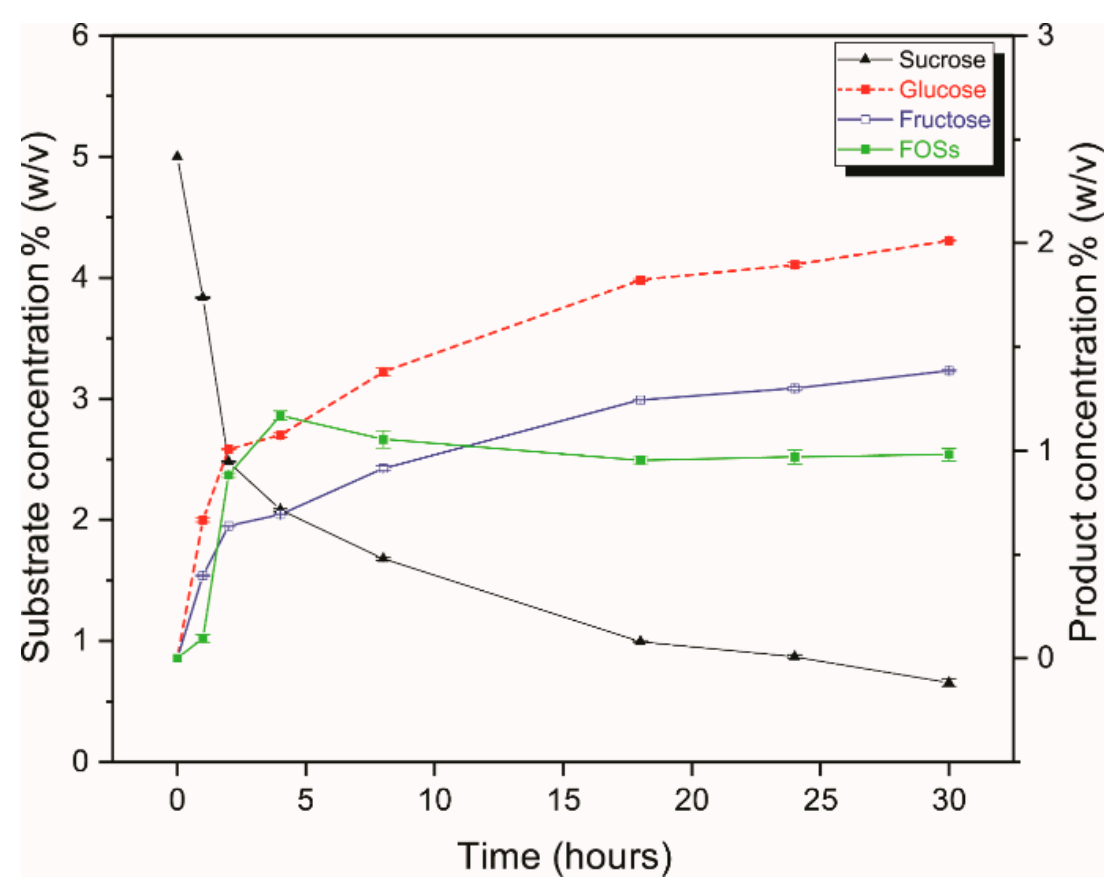

Figure 6. Production of IFOs by R483A-LrInu CLEAs. Reaction condition: $5 \mathrm{U} / \mathrm{mL}$ R483A-LrInu CLEAs, $5 \%(w / v)$ sucrose, $50 \mathrm{mM}$ acetate buffer $(\mathrm{pH} 5.5)$ at $30^{\circ} \mathrm{C}$. The sugar content was analyzed by HPLC with a Sugar-Pak ${ }^{\mathrm{TM}}$ column.

\subsection{Operational Stability of R483A-LrInu CLEAs}

Besides the increase in enzyme stability, the immobilized enzymes are also reusable [44,45]. The operational stability of R483A-LrInu CLEAs was evaluated in a series of batch reactions. As presented in Figure 7, the activity of CLEAs reduced after four cycles of reuse and then remained constant at approximately $45 \%$ of the original activity. The reduction of CLEA activity in early cycles might result from the more compact nature of CLEAs or desorption of non-covalently bound enzyme molecules after recycling of the biocatalyst. This phenomenon was also found in other covalent-immobilized 
enzymes, such as levansucrase immobilized on vinyl sulfone-activated silica [40] and inulosucrase immobilized on core-shell chitosan beads [25].

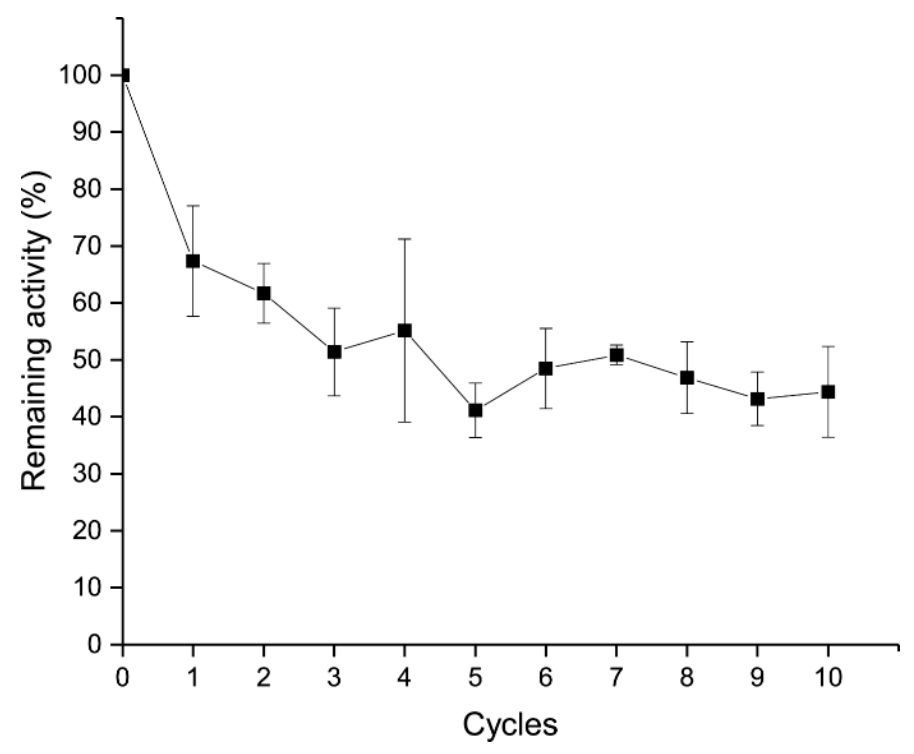

Figure 7. Operational stability of R483A-LrInu CLEAs.

\section{Materials and Methods}

\subsection{Expression and Purification of Inulosucrase Mutant}

The R483A mutant inulosucrase from L. reuteri 121 was expressed and purified according to the method described previously [26]. In brief, the constructed inulosucrase gene was ligated into pET-21b vector (Novagen ${ }^{\mathrm{TM}}$, Madison, WI, USA) via XhoI and NdeI sites. The cloning of a gene into pET-21b introduced a His6 tag on the $C$ terminus of the recombinant protein. The sequence-verified plasmid was transformed into Escherichia coli BL21 (DE3) by electroporation. The recombinant E. coli was cultured in LB broth medium, supplemented with $100 \mu \mathrm{g} / \mathrm{mL}$ ampicillin, $0.5 \%(w / v)$ glucose, and $10 \mathrm{mM} \mathrm{CaCl}$, with shaking at $250 \mathrm{rpm}$ at $37^{\circ} \mathrm{C}$. Once an OD600 reached $0.4-0.6$, isopropyl $\beta$-D-1-thiogalactopyranoside (IPTG) was added to a final concentration of $0.1 \mathrm{mM}$. The cells were further grown by shaking at $200 \mathrm{rpm}$, at $37^{\circ} \mathrm{C}$ for $20 \mathrm{~h}$, and then were harvested by centrifugation at $5000 \times g$ for $20 \mathrm{~min}$.

Cells were disrupted by ultra-sonication and the cell debris was separated from the crude extract enzyme by centrifugation at $12,000 \times g$ for $20 \mathrm{~min}$. The resulting cleared lysate was loaded into a TOYOPEARL TM AF-Chelate-650M column (Tosoh corporation, Tokyo, Japan) pre-equilibrated with $25 \mathrm{mM}$ potassium phosphate buffer ( $\mathrm{pH}$ 7.4). The column was washed with $25 \mathrm{mM} \mathrm{KH}_{2} \mathrm{PO}_{4}$ buffer containing $500 \mathrm{mM} \mathrm{NaCl}$ and $20 \mathrm{mM}$ imidazole ( $\mathrm{pH}$ 7.4). The enzyme was eluted from the column with $25 \mathrm{mM} \mathrm{KH}_{2} \mathrm{PO}_{4}$ buffer containing $500 \mathrm{mM} \mathrm{NaCl}$ and $500 \mathrm{mM}$ imidazole (pH 7.4). The fraction containing inulosucrase activity was collected. A Bradford assay [46] was used to determine the protein concentration.

\subsection{Enzyme Activity Assay}

Inulosucrase activity was determined using a 3,5-dinitrosalicylic acid (DNS) assay [47]. The enzyme was incubated in a substrate solution containing $250 \mathrm{mM}$ sucrose, $50 \mathrm{mM}$ acetate buffer $(\mathrm{pH}$ 5.5), and $1 \mathrm{mM} \mathrm{CaCl}{ }_{2}$ at $50{ }^{\circ} \mathrm{C}$ for $10 \mathrm{~min}$. Then, the reactions were terminated by adding an equal volume of DNS reagent, boiled for $10 \mathrm{~min}$, and the concentration of reducing sugar produced by the enzyme was determined at $540 \mathrm{~nm}$, using a dilution series of glucose concentrations for calibration. A unit of inulosucrase activity was defined as the amount of the enzyme required for release of $1 \mu \mathrm{mol}$ of reducing sugar per minute. 


\subsection{Preparation of Cross-Linked Inulosucrase Aggregates}

For preparing CLEAs, the enzyme is commonly precipitated, followed by cross-linking using bifunctional agents. In this study, precipitating agents, namely methanol, ethanol, 2-propanol, acetone, acetonitrile, and saturated ammonium sulfate, were investigated. Each precipitation agent $(800 \mu \mathrm{L})$ was added to $200 \mu \mathrm{L}$ of inulosucrase solution (to a final concentration of $0.2 \mathrm{mg}$ protein $/ \mathrm{mL}$ ). After keeping the mixture under mild agitation at $4{ }^{\circ} \mathrm{C}$ for $3 \mathrm{~h}$, the precipitated protein was harvested by centrifugation at $10,000 \times g$ for $10 \mathrm{~min}$. The enzyme was re-dissolved in $50 \mathrm{mM}$ acetate buffer ( $\mathrm{pH}$ 5.5) before measuring enzyme activity by the method described above. The precipitating agent that provided the highest recovered activity of inulosucrase was selected for further studies.

Subsequently, the effects of cross-linking conditions, such as glutaraldehyde concentration, $\mathrm{pH}$, and time, were also explored using a suitable precipitating agent. After the enzyme was precipitated, glutaraldehyde was added at different concentrations $(0,0.1,0.2,0.5,1.0,1.5$ and $2.0 \%(v / v))$. The effects of $\mathrm{pH}$ and time for cross-linking efficiency were also determined in the $\mathrm{pH}$ range of 4-8 and for 1-24 $\mathrm{h}$, respectively. The reaction was terminated by adding $0.1 \mathrm{~mL}$ of $1 \mathrm{M}$ Tris- $\mathrm{HCl}(\mathrm{pH} 7.0)$ and CLEAs were collected by centrifugation at $3000 \times g$ for $20 \mathrm{~min}$ and then resuspended in $50 \mathrm{mM}$ acetate buffer ( $\mathrm{pH}$ 5.5). The CLEAs were washed 3 times with ice-cold acetate buffer ( $\mathrm{pH}$ 5.5) and kept in this buffer until further characterization. The percentage of recovered activity of the aggregated enzyme was determined by the total inulosucrase activity of CLEAs/total inulosucrase activity of free enzyme $\times 100$.

\subsection{Biochemical Characterization of Free and CLEAs R483A-LrInu}

The optimal $\mathrm{pH}$ for both CLEAs and free R483A-LrInu was determined by assaying enzymatic activity in the $\mathrm{pH}$ range of 2.0-10.0 using the Britton-Robinson universal buffer [48]. The optimum temperature for both free and immobilized enzymes was also determined by assaying enzymatic activity in $50 \mathrm{mM}$ acetate buffer $(\mathrm{pH} 5.5)$ at a temperature range of $20-70{ }^{\circ} \mathrm{C}$. For analysis of $\mathrm{pH}$ stability, the enzymes were pre-incubated at various $\mathrm{pH}$ levels ( $\mathrm{pH}$ 3.0-8.0) using the Britton-Robinson universal buffer. After that, the residual enzymatic activity was measured by the method described above. The thermostability of both enzyme samples was explored by measuring the enzyme activity after incubation in $50 \mathrm{mM}$ acetate buffer (pH 5.5) with $40 \mathrm{mM} \mathrm{CaCl}_{2}$ at $50{ }^{\circ} \mathrm{C}$ from 0 to $9 \mathrm{~h}$.

\subsection{Oligosaccharide Synthesis and Analysis}

Five units of CLEAs ( $0.09 \mathrm{mg}$ CLEAs) or free inulosucrase mutant were incubated with $1 \mathrm{~mL}$ of $5 \%(w / v)$ sucrose containing $50 \mathrm{mM}$ acetate buffer $\mathrm{pH} 5.5$ and $40 \mathrm{mM} \mathrm{CaCl}_{2}$. The amount of glucose, fructose, and sucrose was analyzed at time points using HPLC with a standard external method. The HPLC system was performed with a Prominence UFLC (Shimadzu Corporation, Kyoto, Japan) fitted with a Sugar-Pak ${ }^{\mathrm{TM}}$ column (Waters Corp., Milford, MA, USA) and a refractive index detector. The samples were separated by $50 \mathrm{mg} / \mathrm{L}$ CaEDTA at a flow rate of $0.5 \mathrm{~mL} / \mathrm{min}$ at $70{ }^{\circ} \mathrm{C}$. The amount of total IFOs was calculated according to the following formula: Total IFOs $[\%(w / v)]=\operatorname{Suc}_{\text {initial }}[\%(w / v)]$ $-\mathrm{Suc}_{\text {remaining }}[\%(w / v)]-$ Glc $[\%(w / v)]-$ Fru $[\%(w / v)]$, where Suc, Glc, and Fru refer to sucrose, glucose and fructose, respectively.

The compositions of IFOs were quantitated by HPLC with an Asahipak NH2P-50 4E column (Shodex, Tokyo, Japan) using $70 \%(v / v)$ acetonitrile as a mobile phase at flow rate of $1.0 \mathrm{~mL} / \mathrm{min}$. Quantitative analysis was performed in triplicate using calibration curves of 1-kestose (Sigma-Aldrich, St. Louis, MO, USA) to determine trisaccharide and nystose (Sigma-Aldrich, St. Louis, MO, USA) to determine tetrasaccharides and longer oligosacchrides. The error bar represented the standard deviation (SD).

HPAEC-PAD was performed by ICS 5000 system (Dionex) and a CarboPack PA1 column at a flow rate of $1.0 \mathrm{~mL} / \mathrm{min}$. The IFOs were separated using a linear gradient of $0-250 \mathrm{mM}$ sodium acetate in $150 \mathrm{mM} \mathrm{NaOH}$ for $30 \mathrm{~min}$. 
The mass of IFOs products was evaluated by MALDI-TOF mass spectrometry (Autoflex speed, BRUKER, Billerica, MA, USA) using 2,5-dihydroxybenzoic acid (DHB) as the matrix.

\subsection{Operational Stability}

The operational stability of R483A-LrInu CLEAs was evaluated by assessing IFOs synthesis in 10 consecutive experimental cycles. The reaction conditions were $5 \mathrm{U} / \mathrm{mL}$ CLEAs, $5 \%(w / v)$ sucrose, and $50 \mathrm{mM}$ acetate buffer ( $\mathrm{pH} 5.5$ ), at $30^{\circ} \mathrm{C}$ for $20 \mathrm{~min}$. After each cycle of operation, the CLEAs were collected by centrifugation at $3000 \times g$ for $10 \mathrm{~min}$. The pellets were washed twice with ice-cold acetate buffer $(50 \mathrm{mM}, \mathrm{pH}$ 5.5). The remaining activity of CLEAs was measured by the method as described above.

\section{Conclusions}

The generation and characterization of CLEAs of L. reuteri inulosucrase mutant (R483A-LrInu) is first reported in this study. In comparison with the soluble inulosucrase, the CLEA-immobilized enzyme has higher $\mathrm{pH}$ stability and thermostability, as well as a promising operational stability for batch production of IFOs. Furthermore, the immobilization also increases the product specificity. Biedrzycka and Bielecka [41] reported that the prebiotic activity of IFOs is mainly dependent on their degree of polymerization, with DP 2-8 showing higher prebiotic activity than DP $>9$ [41]. Hence, the IFOs produced by R483A-LrInu CLEAs may be expected to have a higher prebiotic activity than the IFOs produced by soluble R483A-LrInu. Hence, the overall properties of R483A-LrInu CLEAs make them very attractive as biocatalysts for the synthesis of prebiotic IFOs.

Supplementary Materials: The following are available online at http://www.mdpi.com/2073-4344/9/8/641/s1. Figure S1: MALDI-TOF MS analysis of IFOs synthesized by free and immobilized inulosucrase, Table S1: The recovered activity and immobilization yield of inulosucrase CLEAs R483A-LrInu.

Author Contributions: Conceptualization, T.C. and M.H.P.; validation, T.C., R.P. and M.H.P.; investigation, T.C.; resources, R.P and M.H.P.; writing_-original draft preparation, T.C.; writing-review and editing, M.H.P. and R.A.F.; visualization, T.C.; supervision, M.H.P.; project administration, M.H.P.; funding acquisition, T.C., M.H.P. and R.A.F.

Funding: This research was partially funded by the UK BBSRC Institute Strategic Program on Molecules from Nature (MfN) [BB/PO12523/1] and the John Innes Foundation. The APC was funded by John Innes Centre.

Acknowledgments: TC is thankful for scholarship supports from Science Achievement Scholarship of Thailand (SAST), Faculty of Science Chulalongkorn University and Department of Biological Chemistry John Innes Centre.

Conflicts of Interest: The authors declare no conflict of interest.

\section{References}

1. Macfarlane, S.; Macfarlane, G.; Cummings, J.T. Prebiotics in the gastrointestinal tract. Aliment. Pharmacol. Ther. 2006, 24, 701-714. [CrossRef] [PubMed]

2. Mabel, M.; Sangeetha, P.; Platel, K.; Srinivasan, K.; Prapulla, S. Physicochemical characterization of fructooligosaccharides and evaluation of their suitability as a potential sweetener for diabetics. Carbohydr. Res. 2008, 343, 56-66. [CrossRef] [PubMed]

3. Goosen, C.; Yuan, X.-L.; Van Munster, J.M.; Ram, A.F.; Van der Maarel, M.J.; Dijkhuizen, L. Molecular and biochemical characterization of a novel intracellular invertase from Aspergillus niger with transfructosylating activity. Eukaryot. Cell 2007, 6, 674-681. [CrossRef] [PubMed]

4. Yanai, K.; Nakane, A.; Kawate, A.; Hirayama, M. Molecular cloning and characterization of the fructooligosaccharide-producing $\beta$-fructofuranosidase gene from Aspergillus niger ATCC 20611. Biosci. Biotechnol. Biochem. 2001, 65, 766-773. [CrossRef] [PubMed]

5. Mussatto, S.I.; Aguilar, C.N.; Rodrigues, L.R.; Teixeira, J.A. Fructooligosaccharides and $\beta$-fructofuranosidase production by Aspergillus japonicus immobilized on lignocellulosic materials. J. Mol. Catal. B Enzym. 2009, 59, 76-81. [CrossRef] 
6. Yang, Y.-L.; Wang, J.-H.; Teng, D.; Zhang, F. Preparation of high-purity fructo-oligosaccharides by Aspergillus japonicus $\beta$-fructofuranosidase and successive cultivation with yeast. J. Agric. Food Chem. 2008, 56, $2805-2809$. [CrossRef] [PubMed]

7. Nagaya, M.; Kimura, M.; Gozu, Y.; Sato, S.; Hirano, K.; Tochio, T.; Nishikawa, A.; Tonozuka, T. Crystal structure of a $\beta$-fructofuranosidase with high transfructosylation activity from Aspergillus kawachii. Biosci. Biotechnol. Biochem. 2017, 81, 1786-1795. [CrossRef] [PubMed]

8. Kurakake, M.; Masumoto, R.; Maguma, K.; Kamata, A.; Saito, E.; Ukita, N.; Komaki, T. Production of fructooligosaccharides by $\beta$-fructofuranosidases from Aspergillus oryzae KB. J. Agric. Food Chem. 2009, 58, 488-492. [CrossRef]

9. Jiang, R.; Qiu, Y.; Huang, W.; Zhang, L.; Xue, F.; Ni, H.; Mei, D.; Gao, J.; Xu, H. One-step bioprocess of inulin to product inulo-oligosaccharides using bacillus subtilis secreting an extracellular endo-Inulinase. Appl. Biochem. Biotechnol. 2018, 187, 116-128. [CrossRef]

10. Kim, D.H.; Choi, Y.J.; Song, S.K.; Yun, J.W. Production of inulo-oligosaccharides using endo-inulinase from a pseudomonas sp. Biotechnol. Lett. 1997, 19, 369-372.

11. Ortiz-Soto, M.E.; Olivares-Illana, V.; López-Munguía, A. Biochemical properties of inulosucrase from Leuconostoc citreum CW28 used for inulin synthesis. Biocatal. Biotransformation 2004, 22, 275-281. [CrossRef]

12. Van Hijum, S.; Van Geel-Schutten, G.; Rahaoui, H.; Van der Maarel, M.; Dijkhuizen, L. Characterization of a novel fructosyltransferase from Lactobacillus reuteri that synthesizes high-molecular-weight inulin and inulin oligosaccharides. Appl. Environ. Microbiol. 2002, 68, 4390-4398. [CrossRef] [PubMed]

13. Anwar, M.A.; Kralj, S.; Van der Maarel, M.J.; Dijkhuizen, L. The probiotic Lactobacillus johnsonii NCC 533 produces high-molecular-mass inulin from sucrose by using an inulosucrase enzyme. Appl. Environ. Microbiol. 2008, 74, 3426-3433. [CrossRef] [PubMed]

14. Anwar, M.A.; Kralj, S.; Pique, A.V.; Leemhuis, H.; Van der Maarel, M.J.; Dijkhuizen, L. Inulin and levan synthesis by probiotic Lactobacillus gasseri strains: Characterization of three novel fructansucrase enzymes and their fructan products. Microbiology 2010, 156, 1264-1274. [CrossRef] [PubMed]

15. Frasch, H.-J.; Van Leeuwen, S.S.; Dijkhuizen, L. Molecular and biochemical characteristics of the inulosucrase HugO from Streptomyces viridochromogenes DSM40736 (Tü494). Microbiology 2017, 163, 1030-1041. [CrossRef] [PubMed]

16. Kralj, S.; Leeflang, C.; Sierra, E.I.; Kempiński, B.; Alkan, V.; Kolkman, M. Synthesis of fructooligosaccharides (FosA) and inulin (InuO) by GH68 fructosyltransferases from Bacillus agaradhaerens strain WDG185. Carbohydr. Polym. 2018, 179, 350-359. [CrossRef] [PubMed]

17. Cai, Q.; Hu, C.; Yang, N.; Wang, Q.; Wang, J.; Pan, H.; Hu, Y.; Ruan, C. Enhanced activity and stability of industrial lipases immobilized onto spherelike bacterial cellulose. Int. J. Biol. Macromol. 2018, 109, 1174-1181. [CrossRef]

18. Fernandez-Lopez, L.; Pedrero, S.G.; Lopez-Carrobles, N.; Gorines, B.C.; Virgen-Ortíz, J.J.; FernandezLafuente, R. Effect of protein load on stability of immobilized enzymes. Enzym. Microb. Technol. 2017, 98, 18-25. [CrossRef]

19. Martins, M.; Jing, S.; Fu, J.; Cavaco-Paulo, A. Practical insights on enzyme stabilization. Crit. Rev. Biotechnol. 2018, 38, 335-350.

20. Schoevaart, R.; Wolbers, M.; Golubovic, M.; Ottens, M.; Kieboom, A.; Van Rantwijk, F.; Van der Wielen, L.; Sheldon, R. Preparation, optimization, and structures of cross-linked enzyme aggregates (CLEAs). Biotechnol. Bioeng. 2004, 87, 754-762. [CrossRef]

21. Talekar, S.; Joshi, A.; Joshi, G.; Kamat, P.; Haripurkar, R.; Kambale, S. Parameters in preparation and characterization of cross linked enzyme aggregates (CLEAs). RSC Adv. 2013, 3, 12485-12511. [CrossRef]

22. Talekar, S.; Ghodake, V.; Ghotage, T.; Rathod, P.; Deshmukh, P.; Nadar, S.; Mulla, M.; Ladole, M. Novel magnetic cross-linked enzyme aggregates (magnetic CLEAs) of alpha amylase. Bioresour. Technol. 2012, 123, 542-547. [CrossRef] [PubMed]

23. Li, L.; Li, G.; Cao, L.-C.; Ren, G.-H.; Kong, W.; Wang, S.-D.; Guo, G.-S.; Liu, Y.-H. Characterization of the cross-linked enzyme aggregates of a novel $\beta$-galactosidase, a potential catalyst for the synthesis of galacto-oligosaccharides. J. Agric. Food Chem. 2015, 63, 894-901. [CrossRef] [PubMed]

24. Ortiz-Soto, M.E.; Rudiño-Piñera, E.; Rodriguez-Alegria, M.E.; Munguia, A.L. Evaluation of cross-linked aggregates from purified Bacillus subtilis levansucrase mutants for transfructosylation reactions. BMC Biotechnol. 2009, 9, 68. [CrossRef] [PubMed] 
25. Charoenwongpaiboon, T.; Wangpaiboon, K.; Pichyangkura, R.; Prousoontorn, M.H. Highly porous core-shell chitosan beads with superb immobilization efficiency for Lactobacillus reuteri 121 inulosucrase and production of inulin-type fructooligosaccharides. RSC Adv. 2018, 8, 17008-17016. [CrossRef]

26. Charoenwongpaiboon, T.; Sitthiyotha, T.; Na Ayutthaya, P.P.; Wangpaiboon, K.; Chunsrivirot, S.; Hengsakul Prousoontorn, M.; Pichyangkura, R. Modulation of fructooligosaccharide chain length and insight into the product binding motif of Lactobacillus reuteri 121 inulosucrase. Carbohydr. Polym. 2019, 209, 111-121. [CrossRef] [PubMed]

27. Charoenwongpaiboon, T.; Klaewkla, M.; Chunsrivirot, S.; Wangpaiboon, K.; Pichyangkura, R.; Field, R.A.; Prousoontorn, M.H. Rational re-design of Lactobacillus reuteri 121 inulosucrase for product chain length control. RSC Adv. 2019, 9, 14957-14965. [CrossRef]

28. Yu, H.; Chen, H.; Wang, X.; Yang, Y.; Ching, C. Cross-linked enzyme aggregates (CLEAs) with controlled particles: Application to Candida rugosa lipase. J. Mol. Catal. B Enzym. 2006, 43, 124-127. [CrossRef]

29. Aytar, B.S.; Bakir, U. Preparation of cross-linked tyrosinase aggregates. Process Biochem. 2008, 43, $125-131$. [CrossRef]

30. Xu, D.-Y.; Yang, Y.; Yang, Z. Activity and stability of cross-linked tyrosinase aggregates in aqueous and nonaqueous media. J. Biotechnol. 2011, 152, 30-36. [CrossRef]

31. Sangeetha, K.; Abraham, T.E. Preparation and characterization of cross-linked enzyme aggregates (CLEA) of subtilisin for controlled release applications. Int. J. Biol. Macromol. 2008, 43, 314-319. [CrossRef] [PubMed]

32. Correia, I.; Aksu, S.; Adao, P.; Pessoa, J.C.; Sheldon, R.A.; Arends, I.W. Vanadate substituted phytase: Immobilization, structural characterization and performance for sulfoxidations. J. Inorg. Biochem. 2008, 102, 318-329. [CrossRef] [PubMed]

33. Fazary, A.E.; Ismadji, S.; Ju, Y.-H. Biochemical studies on native and cross-linked aggregates of Aspergillus awamori feruloyl esterase. Int. J. Biol. Macromol. 2009, 44, 240-248. [CrossRef] [PubMed]

34. Talekar, S.; Ghodake, V.; Kate, A.; Samant, N.; Kumar, C.; Gadagkar, S. Preparation and characterization of cross-linked enzyme aggregates of Saccharomyces cerevisiae invertase. Aust. J. Basic Appl. Sci. 2010, 4, 4760-4765.

35. Talekar, S.; Shah, V.; Patil, S.; Nimbalkar, M. Porous cross-linked enzyme aggregates (p-CLEAs) of Saccharomyces cerevisiae invertase. Catal. Sci. Technol. 2012, 2, 1575-1579. [CrossRef]

36. Migneault, I.; Dartiguenave, C.; Bertrand, M.J.; Waldron, K.C. Glutaraldehyde: Behavior in aqueous solution, reaction with proteins, and application to enzyme crosslinking. Biotechniques 2004, 37, 790-802. [CrossRef] [PubMed]

37. Okuda, K.; Urabe, I.; Yamada, Y.; Okada, H. Reaction of glutaraldehyde with amino and thiol compounds. J. Ferment. Bioeng. 1991, 71, 100-105. [CrossRef]

38. Van Hijum, S.A.F.T.; Van der Maarel, M.J.E.C.; Dijkhuizen, L. Kinetic properties of an inulosucrase from Lactobacillus reuteri 121. FEBS Lett. 2003, 534, 207-210. [CrossRef]

39. Karimpil, J.J.; Melo, J.; D'Souza, S. Hen egg white as a feeder protein for lipase immobilization. J. Mol. Catal. B Enzym. 2011, 71, 113-118. [CrossRef]

40. Santos-Moriano, P.; Monsalve-Ledesma, L.; Ortega-Munoz, M.; Fernandez-Arrojo, L.; Ballesteros, A.; Santoyo-Gonzalez, F.; Plou, F. Vinyl sulfone-activated silica for efficient covalent immobilization of alkaline unstable enzymes: Application to levansucrase for fructooligosaccharide synthesis. RSC Adv. 2016, 6, 64175-64181. [CrossRef]

41. Biedrzycka, E.; Bielecka, M. Prebiotic effectiveness of fructans of different degrees of polymerization. Trends Food Sci. Technol. 2004, 15, 170-175. [CrossRef]

42. Ito, H.; Takemura, N.; Sonoyama, K.; Kawagishi, H.; Topping, D.L.; Conlon, M.A.; Morita, T. Degree of polymerization of inulin-type fructans differentially affects number of lactic acid bacteria, intestinal immune functions, and immunoglobulin A secretion in the rat cecum. J. Agric. Food Chem. 2011, 59, 5771-5778. [CrossRef] [PubMed]

43. Cha, X.; Han, S.; Yu, J.; Zhang, S.; Yu, S.; Fu, D.; Yao, M.; Zhang, L.; Feng, G. Inulin with a low degree of polymerization protects human umbilical vein endothelial cells from hypoxia/reoxygenation-induced injury. Carbohydr. Polym. 2019, 216, 97-106. [CrossRef] [PubMed]

44. Garcia-Galan, C.; Berenguer-Murcia, Á.; Fernandez-Lafuente, R.; Rodrigues, R.C. Potential of different enzyme immobilization strategies to improve enzyme performance. Adv. Synth. Catal. 2011, 353, 2885-2904. [CrossRef] 
45. Datta, S.; Christena, L.R.; Rajaram, Y.R.S. Enzyme immobilization: An overview on techniques and support materials. 3 Biotech 2013, 3, 1-9. [CrossRef] [PubMed]

46. Bradford, M.M. A rapid and sensitive method for the quantitation of microgram quantities of protein utilizing the principle of protein-dye binding. Anal. Biochem. 1976, 72, 248-254. [CrossRef]

47. Miller, G.L. Use of dinitrosalicylic acid reagent for determination of reducing sugar. Anal. Chem. 1959, 31, 426-428. [CrossRef]

48. Britton, H.T.S.; Robinson, R.A. Universal buffer solutions and the dissociation constant of veronal. J. Chem. Soc. 1931, 1456-1462. [CrossRef]

(C) 2019 by the authors. Licensee MDPI, Basel, Switzerland. This article is an open access article distributed under the terms and conditions of the Creative Commons Attribution (CC BY) license (http://creativecommons.org/licenses/by/4.0/). 